<原 著 $>$

\title{
経門脈的移植 $\mathrm{AH}$ 66肝癌に対する抗 AFP 抗体の
}

\section{効果に関する研究}

\section{井上 恒雄*}

\begin{abstract}
要 旨: AH 66腹水肝癌を経門脈的にラット肝に移植し, AFP 産生性肝癌に対する抗 AFP 抗 体の抗腫場効果を検討した。抗 AFP 抗体の投与は移植直後, 5 日後および10日後に末梢静脈よ り行い，経時的に血清 AFP 值の測定，生存期間，病理的所見などを検討した。

血清 AFP 值は抗体 $2 \mathrm{mg}$ 投与では対照群と差はなく漸次上昇した。 $4 \mathrm{mg}, 8 \mathrm{mg}$ 投与では 4 日 目に有意に低值であった。生存期間は抗体投与群の抗体の投与量依存性の延長を認め, $8 \mathrm{mg}$ 投 与では非投与群および IgG 投与群との間に有意の差を認めた。組織学的には抗体初回 $4 \mathrm{mg}$ 投与 後の初期例に, 肝類洞内の腫瘍細胞に細胞質の濃縮を認めた。 また腎には軽微な変化をみるの みであった。
\end{abstract}

以上の成績より, 抗 AFP 抗体は遊離肝癌細胞かあるいは橔小な癌に対して, 明らかな抗腫 場効果をるつものと考えられた。

真引用語： 抗 AFP 抗体 AH 66ラット腹水肝癌 AFP AFP 産生性肝癌 経門脈的移植

\section{I. 緒 言}

肝癌の治療成樍は近年漸次向上してきたが，尚切除 以外に根治的治療法はない，したがって治療成績をさ らに向上させるためには補助療法の開発が不可欠であ る.しかし未だ有効な補助療法は少ない。そのだめほ ぼ完全に切除しえた例でる，残存肝に再発を来たして 失亏例も少なくない，その原因には切除断端再発や経 門脈的肝内転移などがある.

Alphafetoprotein (AFP) は，胎生期には胎児卵黄 衰拉よび肝細胞で産生されるが，出生と共に低下し正 常人では血清中に $20 \mathrm{ng} / \mathrm{m} l$ 以下に存在するにすぎな い、しかし肝細胞癌, 肝芽腫あるいは卵黄襄腫などが 発生すると、これら癌細胞の多くのものは AFP 産生 能であるため, 再び血中の AFP 值は上昇してくる.し たがって，今日ではAFPはこれら AFP 産生腫瘍の診 断や治療奻果の判定上重要な指標となっている.

一方, AFP は癌細胞が産生する特異蛋白であること から, AFP 産生腫場に対する抗 AFP 抗体は診断のみ ならず治㞠の観点からす興味のあるところであり， 種々の研究が行われてきた。

- 北海道大学医学部第 1 外科学教室 $<$ 受付日59年 5 月 18 日 $>$ in vitro では塚田 ${ }^{11}$, 内野ら ${ }^{21}$ は, 抗 AFP 抗体に AFP 産生細胞に対する dose-dependentでかつ AFP 産生 性の高い程つよい抗腫煌効果を認めている.

一方, in vivoであ真鍋3, 宇根)らは, ヌードマウス 移植ヒ卜肝癌および AH 66移植肝癌, DAB 肝癌につ いて恰討している．その成績によると，その抗腫瘍効 果は in vitrok比し低く，小さな腫鈞に対してのみ縮 小効果を示すのみで，生存期間の延長に結びっくもの ではなかった。

また，臨床的検討も行われているが5)，いまだ充分な 成績は得られていない。

そこで，著者はAFP高産生性である AH 66 ラット 腹水肝癌細胞を程門脈的に移植し，微細肝内転移巣に 対する抗 AFP 抗体の効果を検討し，2，3の新知見を 得たので報告する。

\section{II. 実験方法}

AH 66 ラット腹水肝癌細胞を門脈内に注入移植した ラットに抗 AFP 抗体を静注投与し, その抗腫湯効果 を検討した。

\section{1. 実験動物ならびに材料}

1）実験動物

実験動物は雄性の近交系 Donryu-Rat で，週龄的10 週, 体重約300gのものを用いた。飼育は室温下で行い, 
水と飼料は ad libitum に与えた。

\section{2) 腫湟}

腫湯は AFP 高産生性のAH 66ラット腹水肝癌細胞 を用いた，腹腔内に継代維持されているラットより， 腹腔穿刺により腹水と共にAH 66を採取し，これを生 理食塩水で稀釈して, $5 \times 10^{6}$ 個 $/ \mathrm{m} l$ の細胞浮遊夜を作 成した。細胞の viability は trypan blue 染色により判 定し，実験開始の前後において差異のないよ5に行っ た.

\section{3) 抗 AFP 抗体}

抗 AFP 抗体はまず精製したラットAFPを用いて ウマを免疫し,ウマ抗ラットAFP血清を作成した。つ いでラットAFPをセフフロース4Bに結合させた affinity columにこれを通し、ラットAFPとのみ結合 する IgGを精製分離した。 この抗体 $1 \mathrm{mg}$ は約 $150 \mu \mathrm{g}$ の AFP と結合することが確認されている6).

\section{2. 実験方法}

\section{1）腫漡移植方法}

ラットをエーテル吸入麻酔下で開腹した。ついで腸 間膜根部にて門脈を露出後, 26ゲーシ針付ッベルクリ ン注射器を用いてこれを穿刺し，細胞浮遊液の $\operatorname{lm} l$ を 注入した．針の刺入部位は腸間膜根部付近で行い，針 先を門脈本幹の方向にすすめた。浮遊液の注入には 40〜50秒をかけて緩徐に行った。針抜去後の刺入部よ りの出血を指頭または綿棒による王迫により止血し た。腹壁は二層に連続䋖合で閉鎖した。これら全操作 に要した時間は10〜15分であった。

2) 抗 AFP 抗体投与方法と実験群

奏験群は抗体の投与量括よび対照により以下の 3 群 に分けた。

\section{I：尰瘍接種のみを行った群}

II：正常ウマ免疫グロプリン（IgG）を投与した群

III：抗 AFP 抗体を投与した群

さらに II 群は IgGの投与量により $2 \mathrm{mg}$ 投与の IIa, 4 $\mathrm{mg}$ 投与の IIb, $8 \mathrm{mg}$ 投与の IIc の 3 亜群に分けた。 ま たIII群も同様に抗 AFP 抗体の投与量により，2mg 投 与の IIIa, $4 \mathrm{mg}$ 投与の IIIb, $8 \mathrm{mg}$ 投与の IIIc の 3 亜群 を作成した。

各実験群に使用したラットは7〜10匹であったが， 麻酔死き腹壁創哆開などによる死亡のため, 結局評価 の対象となったものは6ー9匹であった（Table 1).

抗体扰よびIgGは閉腹直後に全投与量の $1 / 2$ を陰茥 静脈より注入した。ついで5日目および10日目にそれ ぞれ1/4量を尾静脈または陰茥静脈より投与した。投与
Table 1 Experimental Groups.

\begin{tabular}{c|c|cc|c}
\hline \multicolumn{2}{c|}{ Group } & \multicolumn{2}{c|}{ Dosis } & $\begin{array}{c}\text { Number } \\
\text { of rats }\end{array}$ \\
\hline \multirow{4}{*}{ I } & \multicolumn{2}{|c|}{ none } & 9 \\
\hline \multirow{4}{*}{ II } & a & IgG & $2 \mathrm{mg}$ & 7 \\
\cline { 2 - 6 } & b & IgG & $4 \mathrm{mg}$ & 8 \\
\cline { 2 - 6 } & c & IgG & $8 \mathrm{mg}$ & 7 \\
\hline \multirow{4}{*}{ III } & a & AAA & $2 \mathrm{mg}$ & 7 \\
\cline { 2 - 6 } & b & AAA & $4 \mathrm{mg}$ & 8 \\
\hline & c & AAA & $8 \mathrm{mg}$ & 6 \\
\hline
\end{tabular}

AAA ; Anti-alphafetoprotein antibody

はいずれる $\operatorname{lm} l$ に調整して行った。

3. 検索, 測定項目

1) 程門脈的移植 AH 66肝癌の性状

実験モデルとして本法は他の報告が少ないので，ま ず作製された肝癌の性状について以下の検索を行。 た.

AH 66 細胞 $5 \times 10^{6}$ 個 $/ \mathrm{m} l$ を門脈内に注入後 1,3 , 5,7 日目に開腹し,肝の肉眼的所見扣よび病理組織学 的所見を検索した。

2) 血清 AFP 值

腫浯接種後 1，4，7，10および14日目，以後は約 10 日 ごとに生存しているすべてのラットの血清 AFP 值を 測定した。採血は尾静脈小切開により行い, へマトク リット毛細管を用いて採取したのち，ただちに5,000 回/分，5分間遠沈して血清を分離した．これらの血清 は $4{ }^{\circ} \mathrm{C}$ に保存し, 後日まとめて Radioimmunoassay により血清 AFP 值の測定を行った.

3）生存期間および生存率

各実験群について、每日ラットの生死を確認し，生 存日数を調べた.これにより释日的に生存率を算出し， 生存曲線をつくり，生存曲線の統計的解析，50\%生存 率などについて検討した．統計的解析は分散分析法に より行った。

4) 病理学的所見

ラットは死亡後全例を解剖し，肝，肺，腎，脾等の 性状や腹水の有無などの肉眼的所見について検索し た。

また，肝，肺，腎，脾を10\%ホルマリンに固定し， パラフィン包埋後薄切し, HE 染色および PAS 染色 後, 光学顕微鏡にて検索した。

長期生存例は60日後に全例屠殺し，同様の検索を 行った。 


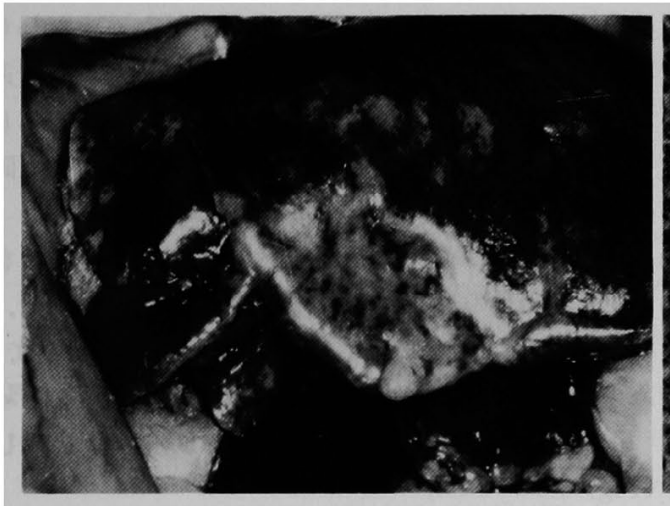

(a)

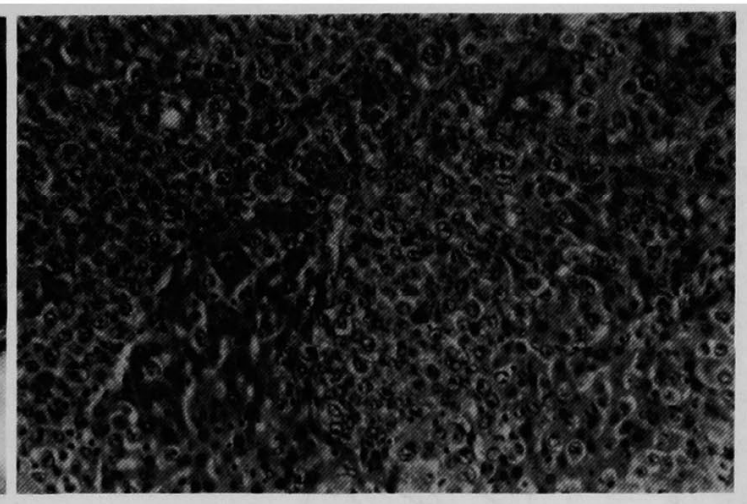

(b)

Fig. 1 Macroscopic finding (a) and histology (b) of the liver; 7days after injection of $\mathrm{AH} 66$ hepatoma cells; $\mathrm{H}-\mathrm{E} \times 100$.

初回4mg の抗体投与群および IgG 投与群について は $1,3,5,7$ 日目の肝および腎の病理学的検索を 行った.

\section{III. 実験成績}

\section{1. 経門脈的移植 AH 66肝癌の性状}

1) 肉眼的所見

睡湯接種後 1 および 3 日目には，肝の表面招よび割 面にとくに腫瘍の形成あるいはこれを示唆するものを 認めなかった。

5 日目では，肝表面掞よび割面に散在性，多発性の 莱粒大結節がみられ，これらは肝辺縁または被膜下周 辺に多くみられる傾向があった。7日目では，結節の 数, 大きさともに増大し, 一部は融合して塊状になる 傾向もみられた（Fig. 1, a).

2) 組織学的所見

腫瘍接種 1 日目には類同に補捉された腫瘍細胞が散 在性にみられ，3日目にはこれが増大し，巣状の増殖 を示した。

5 日目には, さらに結節数の増加と各結節の増大が みられ，周囲正常肝組織を圧迫している所見すあった， 7 日目の所見では，病巣の増大が著しく，正常肝組織 がほとんどみられない部分.も多かった，腫瘍内出血， クッパー細胞の遊走などは認めなかった（Fig. 1, b).

\section{2. 血清 AFP 值}

血清 AFP 值の推移をまず14日目までについてみる と, I 群では 1 日目 $1.1 \pm 0.1 \mu \mathrm{g} / \mathrm{m} l$ で以後直線的に上

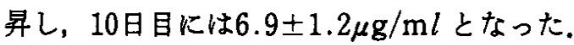

II 群ではIIc 群がやや高値の傾向にあったが，IIa， IIb 群はI 群とほぼ同様の推移を示し, I 群に比し有 意に低値を示したものはなかった（Fig. 2).

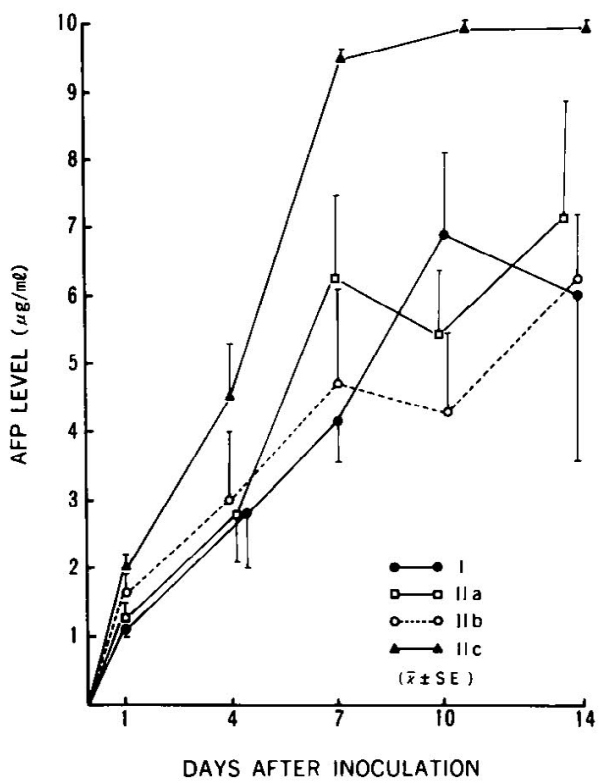

Fig. 2 Serum AFP levels after inoculation in group I and IIa, b, c.

III群ではIIIa 群はI群とはぼ同じ推移を示した。し かし IIIb 群は 1 日目0.5 $00.3 \mu \mathrm{g} / \mathrm{m} l$ と低値であり， 4 日目は $0.7 \pm 0.3 \mu \mathrm{g} / \mathrm{m} l$ と I, II 群に比し有意の低値 を示した。しかし 7 日目以後は上昇傾向を示し，他群 との間に有意の差を認めなかった。

一方, IIIc 群は IIIb 群と同様に 1 日 目 $0.5 \pm 0.2 \mu \mathrm{g} /$ $\mathrm{m} l$ と低い傾向にあり， 4 日目には $0.7 \pm 0.2 \mu \mathrm{g} / \mathrm{m} l$ と 有意に低値を示した。また 7 日目でも他群に比し低い 傾向がみられ，IIIb群とはやや異なる推移を示した (Fig. 3). 


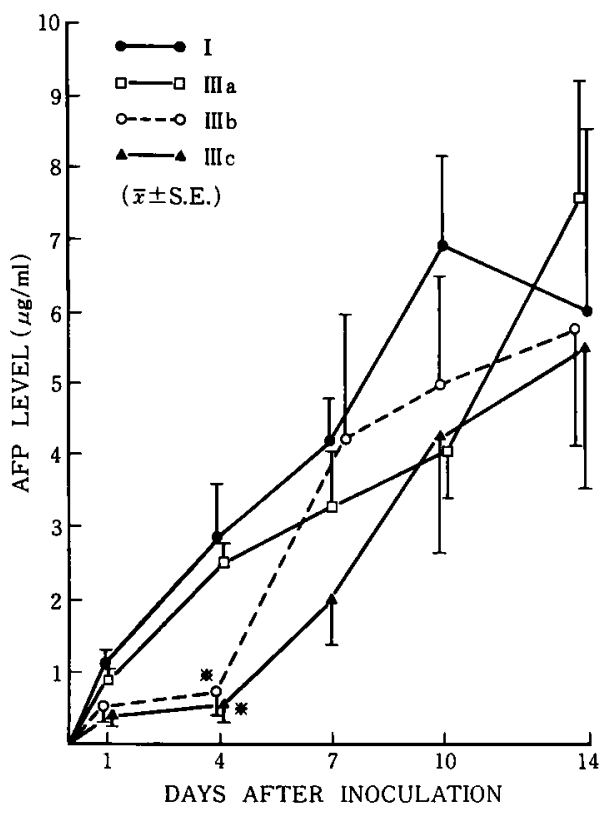

Fig. 3 Serum AFP levels after inoculation in group I and IIIa, b, c.

14日目以後の血清 AFP 值は, I, IIb 群ではさらに上 昇をつづけ，それぞれ15日，21日までに全例が死亡し た。しかしIIIb 群では AFP 値は20日目にピークに達 するが，その後は徐々に下降し，60日目には68土41ng/ $\mathrm{ml}$ であった (Fig. 4). IIIa, c 群です IIIb群と同様の 傾向を示し，約20日後にビークを示し，その後下降し た。

ついで血清 AFP 值の推移を個々のラットについて
みると，次の 4 つのタイプに分類された。すなわち，

A：早期に上昇し死亡するすの，B：1 週以降 3 週頃 までに上昇し死亡するすの，C：3週以降に上昇し死 亡するるの， D：一時軽度の上昇をみるが漸次下降し 長期生存するすの (Fig. 5).

各実験群におけるこれら各タイプの占める割合をみ ると，I，IIa，b，c 群では全例がAまたはBであり，C， Dはみられなかった．これに対して IIIa，b，c 群では， Aは 1 例もなく, IIIb, c 群では C, D が50\%を占めた (Table 2). 長期生存例はすべて Dの推移を示した (Fig. 6).

以上のよ5に，抗体投与により早期の血清 AFP 值 の上昇は抑制され，上昇時期の遅延を認めた。また， この効果は抗体投与量依存性であった。

\section{3. 生存期間书よひ生存率}

平均生存日数は，I 群では11.4 b，c群はこれと有意差がなかったＩII群では各亜群と る生存日数の著明な延長を示し，I群との間に有意の 差を認めた（Fig. 7).またIIa と IIIa, IIb と IIIb 各群 の間には有意差はなかったが，IIcと IIIc 群間の差は 有意であった。 またIIla，b，c 群間に有意差はなかっ た。

つぎに生存曲線を I 群, IIa, b, c 群について検討す ると，12日後の生存率は，IIb，c群ではそれぞれ $62.5 \%, 57.1 \%$ でり, I 群の33.3\%, IIa 群の $28.6 \%$ に比して高かった，しかし生存曲線全体の解析では,

I, IIa, b, c 各群間に有意の差はなかった。

I 群と IIIa, b, c 群の生存率を比較すると, 12 日後の

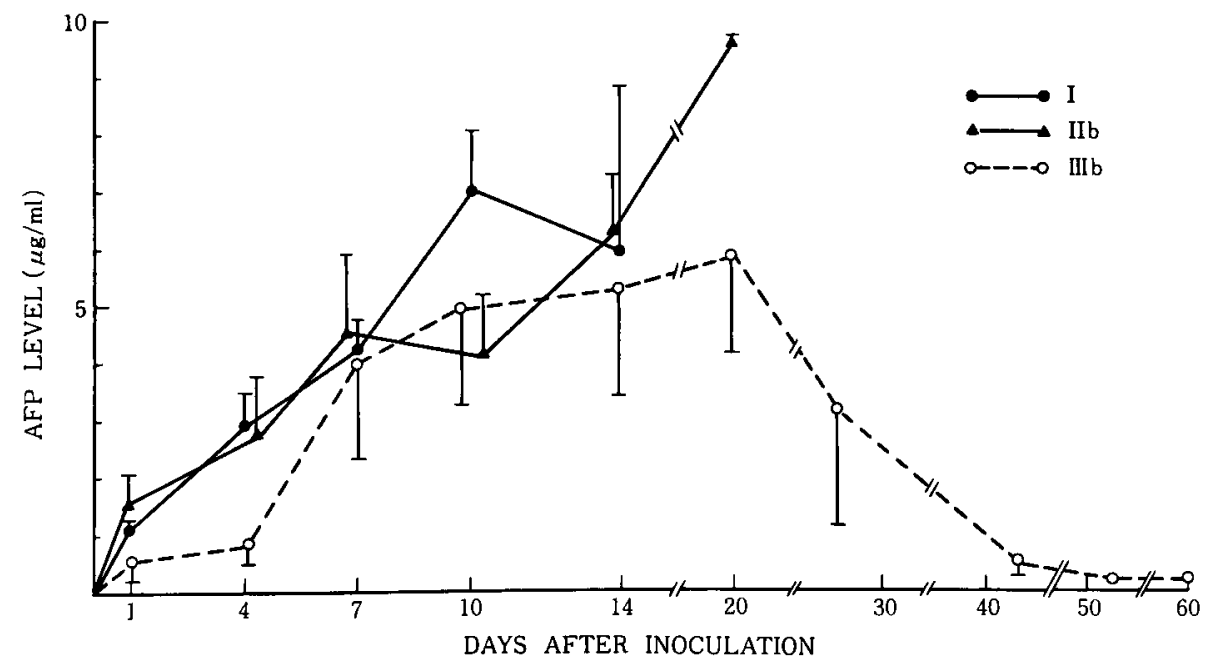

Fig. 4 Serum AFP levels during 60days after inoculation in group I, IIb and IIIb. 


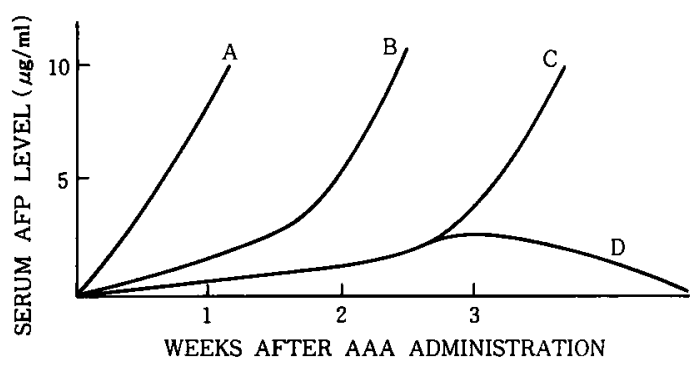

Fig. 5 Various types of change in the serum AFP level.

IIIa, b, c 各群はほぼ同值の83〜87\%であり，I 群に比 し著明に高かった。 また生存曲線全体の解析です, IIIa， b, c 各群は I 群に比し有意の生存期間の延長を認めた （p<0.05）(Fig. 8). IIIb, c 群は IIIa 群に比し生存期 間延長の傾向がみられたが，IIIa，b，cの各亜群間には 有意の差はなかった.

また I 群の50\%生存は12日であり，IIa, b, c 群はこ れと有意の差がなかった。しかしIII群では各亜群とも I 群より長く, IIIa 群16日, IIIb 群24日, IIIc 群29日で, 抗体投与量依存性の延長を示した。

長期生存例はIII群のみに認められ，IIIa 群では 7 匹 のうち 1 匹, IIIb 群では 8 匹のうち 2 匹, IIIc 群では 6 匹の5ち1匹であった (Table 3).

つぎにII群とIII群をIgGと抗体の投与量により比 較すると, IIa 群と IIIa 群では12日および15日後の生
Table 2 Groups and types of the course of AFP levels.

\begin{tabular}{|c|c|c|c|c|c|}
\hline \multicolumn{2}{|c|}{ Groups $T$ Type } & A & B & C & D \\
\hline \multicolumn{2}{|c|}{ I } & $3(33)$ & $6(67)$ & $0(0)$ & $0(0)$ \\
\hline \multirow{3}{*}{ II } & a & $1(14)$ & $6(86)$ & $0(0)$ & $0(0)$ \\
\hline & b & $3(38)$ & $5(62)$ & $0(0)$ & $0(0)$ \\
\hline & c & 1 (14) & $6(86)$ & $0(0)$ & $0(0)$ \\
\hline \multirow{3}{*}{ III } & a & $0(0)$ & $6(86)$ & $0(0)$ & $1(14)$ \\
\hline & b & $0(0)$ & $4(50)$ & $2(25)$ & $2(25)$ \\
\hline & c & $0(0)$ & $3(50)$ & 2 (33) & $1(17)$ \\
\hline
\end{tabular}

存率は IIIa 群がIIa 群より高く，生存曲線上でも生存 期間の延長傾向が少られたが，統計学的には有意では なかった(Fig. 9). IIb 群と IIIb 群では，IIIb 群に生存 期間の延長する傾向をみたが, IIb 群にも生存延長の 傾向があり，全体としては両群間に有意差はなかった (Fig. 10).

IIc 群とIIIc 群では，12日後の生存率はそれぞれ $57.1 \% ， 83.3 \% ， 15$ 日後の生存率はそれそれ $14.3 \%$, 83.3\%であり, 分散分析法による生存曲線の解析でも, IIIC 群は IIC 群に比し有意の生存期間の延長を認めた $(\mathrm{p}<0.05)$ (Fig. 11).

以上のよ5に, 腫場接種のみの群と抗体投与群との 間に有意の生存期間の延長を認めた。また抗体 $8 \mathrm{mg}$ 投

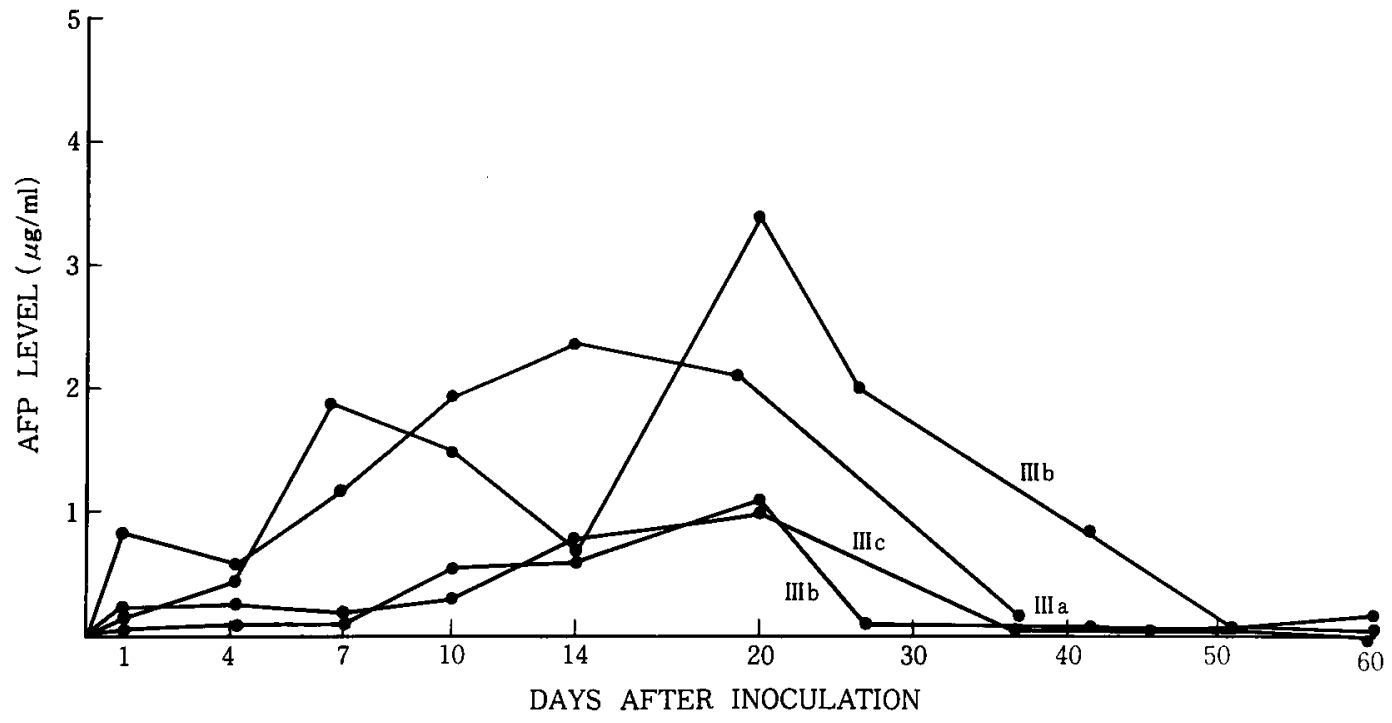

Fig. 6 Serum AFP levels in long survived rats. 


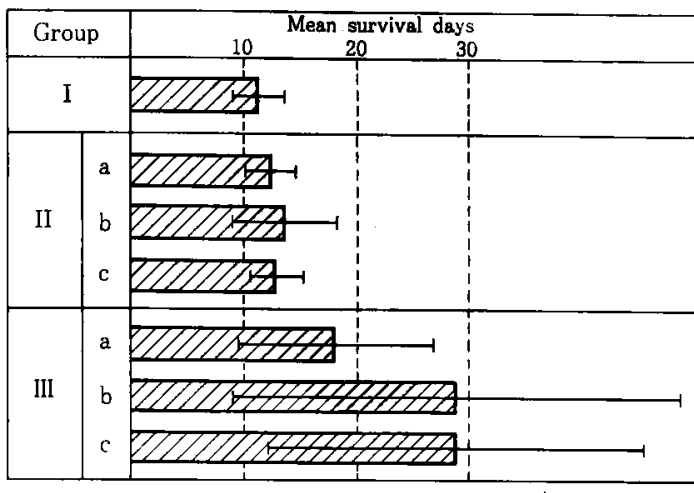

( $\bar{x} \pm$ S.D. $)$

Fig. 7 Mean survival days.

与群では IgG 投与群との間にも有意差を認めた。

\section{4. 病理組織学的所見}

経過中死亡例の肝の肉眼所見は， I， II，III各群間 に差はなく，ほぼ全葉にびまん性に多結節性の睡瘤を 認め, 一部塊状のものもあった。 また脾, 腎は肉眼的 にとくに異常所見を認めなかった。
Table 3 Percentages of long survived rats.

\begin{tabular}{c|c|c|c}
\hline Group & $\begin{array}{c}\text { Number } \\
\text { of rats }\end{array}$ & $\begin{array}{c}\text { Number of } \\
\text { long survived rats }\end{array}$ & Percentages \\
\hline \hline III a & 7 & 1 & $14 \%$ \\
\hline III b & 8 & 2 & $25 \%$ \\
\hline III c & 6 & 1 & $17 \%$ \\
\hline
\end{tabular}

死亡例の肝の組織所見では，I，II，III各群間に差 はなく，多結節性に密なシート状増殖を示し，中心壊 死や出血のみられるものがあった。

腎の組織所見では，IIIc 群で抗体投与後24時間の尿 細管，基底膜に変化はなく，系球体メサンギウム細胞 の軽度の増加を認めたものがあった．IIIc 群の死亡時 では，来球体，尿細管の出血や基底膜の肥厚などは認 められなかった。

長期生存例の60日目屠殺時の肉眼所見では，肝，肺 に腫瑒は認めず，堅脾にとくに所見なく，肝縁の鈍 化を認めるだけであった。

組織学的には肝のグリンン鞘および肺胞壁に単核細

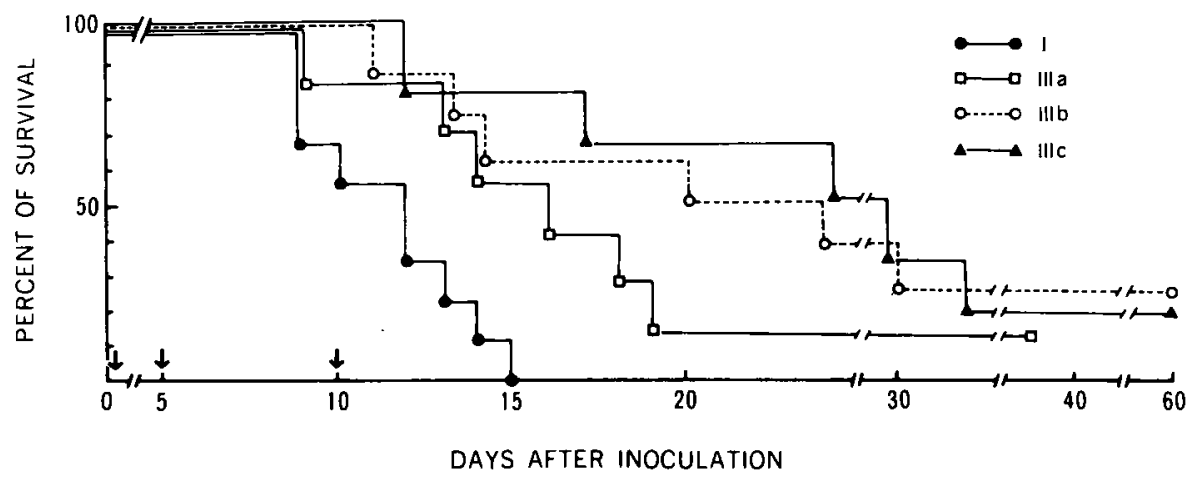

Fig. 8 Survival rates in group I and IIIa, b, c.

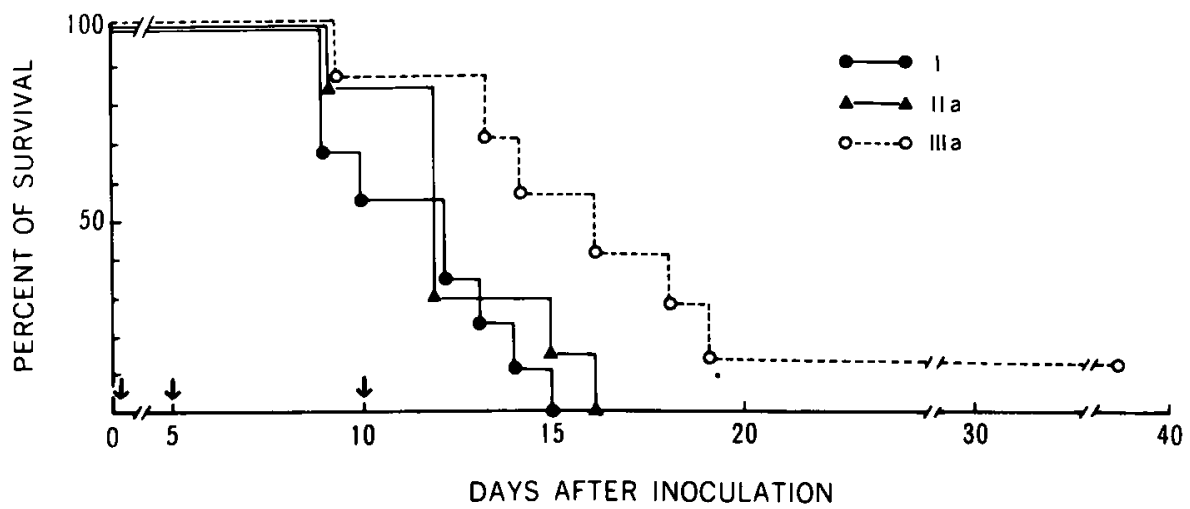

Fig. 9 Survival rates in group I, Ila and IIIa. 


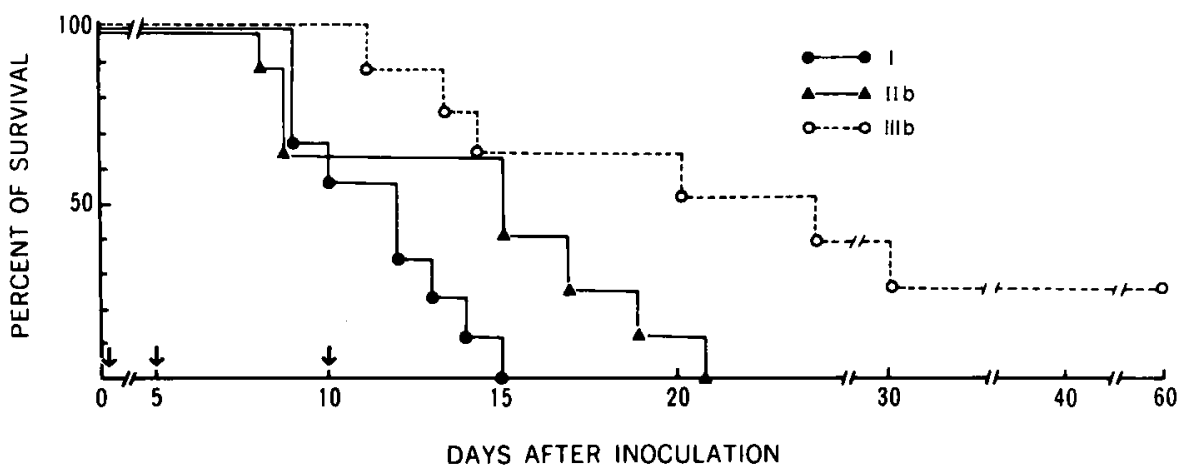

Fig. 10 Survival rates in group I, IIb and IIIb.

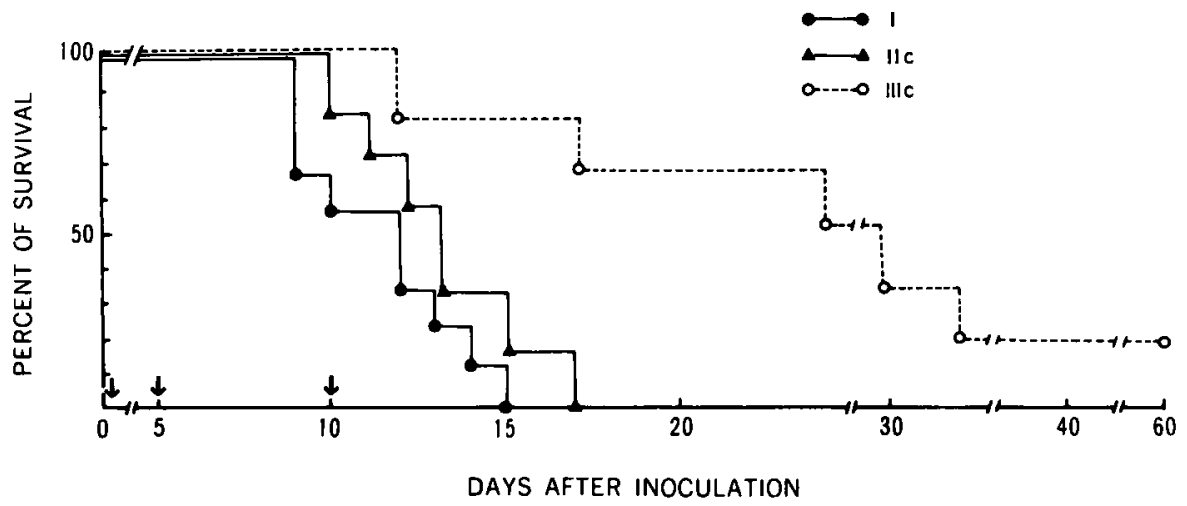

Fig. 11 Survival rates in group I, IIc and IIIc.

胞の軽度の浸閏をみるるのがあったが，全体としては 正常であった.

IIIc 群の抗体投与後の肝の経日的組織所見では，1 日目に類洞に補捉された腫湯細胞は核がクロマチンに よく染まり，核構造は不明であった，細胞質は強く好 酸性に染まり，濃縮傾向にあった。これらの所見は漸 次軽減し，7日目にはほとんど認めなかった。

一方, IIc 群では IIIc 群におけるような腫瘍細胞の 変化はみられなかった. また IIIc 群はI, IIc 群に比し， 3 および 5 日後腫場細胞の集簇は小さく, 増殖が抑制 されていることが推定されたが，定量的には表現でき なかった。

\section{IV. 考 察}

AFP は最初 Abelev ら》により移植肝癌の宿主マウ スの血清中に証明され，ついでとト肝癌患者血清中に 検出されてから，肝癌のマーカーとして診断上有力な 指標となった. 一方, AFP の生化学的研究がすすめら $れ^{8)}$, Radioimmunoassay に上る测定法が確立され，微 量 AFP の湘定が可能となった結果，訮炎や訮硬変の
みならず正常人血清中にも微量ではあるが AFP が存 在することが明らかとなった。

一方，AFP は抗原性を有し，これに対する抗 AFP 抗体の作製と精製が可能となったことから，抗 AFP 抗体の AFP 産生腫晹に対する抗腫湯効果が注目され るようになっだ.

抗 AFP 抗体の AFP 産生細胞に対する細胞障害性 は, Tsukada らいによりはじめて in vitroで証明され た.すなわち抗 AFP 抗体は AH 66培養細胞のらち AFP 産生細胞に特異的に結合し，その増殖を抑制する ことを証明した. その後, Mizejewski ら ${ }^{10)}$ BW 7756 マウス肝癌細胞を用いて同様の成績を報告した。

以後，抗 AFP 抗体の抗厘湯効果に関する研究は主 として本邦を中心に行われてきた。すなわち in vivo 実験としては, 金田ら ${ }^{11}$ による DAB 肝癌発生の抑制,

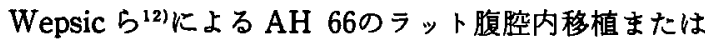
皮下移植に対する抑制効果，真鍋 ス継代移植ヒト肝癌における検討などがある。これら の成績はいずれも抗 AFP 抗体により AFP 産生腫湟 
の発育が抑制されることを証明している。

肝に局在する肝癌に対する AFP 抗体の効果は宇 根市の報告のみにみられる。それによれば，DAB 肝癌 およびラット肝に移植した孤立性 AH 66肝癌に対し て抗 AFP 抗体は, 血中 AFP 值上昇の抑制之腫瑒体積 $110 \mathrm{~mm}^{3}$ 以下の腫場に対する樎小効果をみとめたとい 5 .

本実験では経門脈的に移植した AH 66に早期に抗 AFP 抗体を投与して, in vivoに打ける遊離肝癌細胞 あるいは微細な盾場に対する効果を研究した。

腫瘍細胞の経門脈的注入による肝癌の作成は, Fisher $ら^{13)}$ にる Walker carcinoma 256を Sprague Dawley rat の腸間膜静脈に注入した例や，Yukaya ら ${ }^{14)}$ の AH-100B Donryu rat の門脈に注入した例 などがある。

AH 66を門脈内に注入すると，ます類洞に補捉され， そこで多数の癌巣を形成しさらに増殖, 増大する.こ れにともない血清 AFP 值は上昇し, 担癌ラットは最 終的には癌死する.したがって臨床的にみれば，その 態様は必ずしも一致しないが, 肝癌の経門脈転移の一 面を示すものと考えられる。

${ }^{131}$ I 標識抗 AFP 抗体はAFP 産生性肝癌細胞 合する ${ }^{15)}$. 抗体の効果は局所的に高濃度に投与すれぱ より大きいことが推測される4. 一方, 投与抗体が血清 AFP 量より著しく少ない状態すなわち antigen excessの状態でも畽場に集皘することが証明されて いる ${ }^{16)}$. また抗 AFP 抗体の抗腫場効果は睡湯量依存 性であり, 畽瘍量の小さいものほど効果は大きいこと

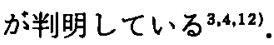

本実験では，抗体の投与は末梢静脈より行った．投 与抗体量は他の報告のすのに比してむしろ少量であ ク，たとえば4mg 投与では，体重比で60kg の人間に換 算して $800 \mathrm{mg}$ 投与に相当する. 抗缠瘍効果が比較的明 確に表現されたのは腫煬接種直後の投与であり，これ は腫瘍細胞がまた遊離状態であったことがもっとも大 きな要因と考えられる。しかし腫瘍量の少ない時期で あったことも関与しているものと思われる.

宇根》に上机ば, 血中 AFP 值は抗体投与後一時低下 するが， 1 週間後には対照と差異がなくなったにもか かわらず，畽場の大きさは対照群に比し明らかに小さ かったとい5。著者の実験でも, 抗体投与後に低值で あった血清 AFP 値は，7日目には上昇したにもかか わらず生存期間は延長しておう，同しょらな成績で あった。
これは血中 AFP 值と腫湯の増殖能力, 増殖速度は 必ずしも比例関係にはないことを示している，細胞增 殖とAFP 分泌とは，むしろ反比例関係にあり，体蛋白 合成の盛んな時期にはAFPのような分泌型蛋白合成 はむしろ抑制される ${ }^{17)}$.

抗体投与により初期に低值であった血清 AFP 值は 急上昇し，7日後には他群との差を認めなくなった。 これは抗 AFP 抗体の効果の持続時間および半減期, ラットAFPの代謝, AH 66細胞の AFP 高産生性と血

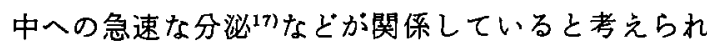
る.

抗体投与量と生存期間の延長をみると, $8 \mathrm{mg}$ 投与群 では他群に比し有意の延長を諗めた。 また抗体 $2 \mathrm{mg}$ お よび4mg 投与群では, 生存期間延長の傾向は著明で あったが, IgG 投与群との間に有意差はなかった. IgG 投与群に長期生存例はなかったが，抗体投与群では 21 例中 4 例（19\%）の長期生存例を認め，これらはいす れも60日後腫煌を肝に証明することはできなかった。

肝に局在する畽場に対して抗 AFP 抗体を投与し， 生存期間の延長を認めた実験は他に見当らなかった。

抗 AFP 抗体の AFP 産生細胞に対する発育抑制効 果の発現機序としては，まず抗体が細胞表面に付着す ることによる直接的細胞障害の可能性 ${ }^{1,12)}$ がある。また 局所の Arthus type tissue destructionの可能性 ${ }^{10}$ む 考えられる。

AH 66は多数のクローンよりなることが明らかにさ れており、AFP 非産生または低産生細胞が約 $20 \%$ ふく まれている ${ }^{18)}$.したがって本実験で抗体投与例の $19 \%$ のものに腫㻛が消失したことは直接的細胞障害作用の みでは説明のつかない現象である。これに対しWepsic ら ${ }^{121}$ は細胞表面における抗原抗体反応の結果, 新た に抗原性を獲得し，宿主側の免疫能が相対的に上昇す る可能性を示唆している.

一方, AFP 非産生とされる細胞の中には，ごく少量 の AFPを産生するものるありらるし，また AFP 非産 生であってもAFP 産生細胞と共通の抗原を持っこと が推測される.これによる障害性が誘発されるすのと あ考えられる。

さらに本実験においては，抗体により移植された $\mathrm{AH}$ 66細胞の細胞膜の変化が惹起されるため, 肝への 着床が抑制され，なた着床しても細胞の AFP 産生能 や增殖能は抑制された状態にあるものと思われる.

しかし肉眼的には抗体の投与, 非投与による睡場の 性状に著明な差異はなかった。しかし組織学的に，抗 
体投与後早期に移植腫湯細胞の核の濃染と構造の不明 瞭化, 細胞質の濃縮像などの変性所見が観察された。 これは抗 AFP 抗体の影響が組織レベルでとらえられ た最初のるのと考えられる.

抗 AFP 抗体投与の副作用として，異種蛋白による 過敏症がもっとも大きな問題となる。これまでの報告 では動物実験上す臨床上す重篤なるのは見られていな ( 3 5,16). 本実験です抗体投与後24時間で腎に軽儌な変 化をみたが，この变化は非特異的かつ可逆的なもので あった. したがって副作用は無視しらる程度の軽微な あのと考えられるが，なお慎重な検討を続ける必要は ある.

AFPに対するモノクロナール抗体 ${ }^{19)}$ を用いること により抗体の頻回投与は可能となるので, AFP 抗体療 法はさらにより頻回により大量に投与する方法より検 討する必要がある201.一方, 抗癌剂との conjugateによ る missile 療法の可能性についても今後検討すべきも のと考える。

\section{V. 結 語}

AH 66ラット腹水肝癌細胞を経門脈的に移植した ラットに対して, 抗 AFP 抗体を投与し, その効果を検 討し，以下の結論を得た。

1. 血清 AFP 值は抗体 $2 \mathrm{mg}$ 投与群では対照群と同 じであったが，4,8mg 投与群では 4 日目に有意に低值 であった。

2. 抗体投与により著明な生存期間の延長をみた。非 投与群での平均生存日数は11.4日であるのに対して抗 体4mg および8mg 投与群では，それぞれ29.0日，29.0 日であった。

3.これらの抗腫瘍効果は抗体投与量依存性であっ た.

4. 長期生存例は抗体投与群のみに $19 \%$ 認め, 60 日後 剖検で尰場を認めなかった。

5. 組織像上, 抗体投与により早期に腫瘍細胞の濃縮 像をみたか，特異的な変化は認めなかった。

以上より, 抗 AFP 抗体は AH 66経門脈的移植肝癌 に対して投与量依存珄の抗隀瘍効果を有すると結論さ れた。

本実崄に使用した AH 66細胞および抗 AFP 抗体は, 本 学第 1 生化学教室より供与された。

稿を終るにあたり, 葛西洋一教授の御指導, 御校閲に深謝 する.また抗 AFP 抗体に関して御指導いただいた本学第 1 生化学讙座平井秀松前教授ならびに塚田裕助数授，また病
理組織学的検索の御教示をいただいた本学第 1 病理学講座 相沢幹教授ならびに市立札幌病院病理部伊藤哲夫博士に謝 意を表する.協同研究者としての内野純一助教授，泰温信助 手, 宇根良衛博士に感謝する。

本論文の要旨は第40回日本癌学会総会, 第41回日本癌学 会総会および第18回日本肝脭学会総会において発表した。

\section{文献}

1) Tsukada Y, Mikuni $\mathrm{M}$, Watabe $\mathrm{H}$, et al : Effect of anti-alpha-fetoprotein serum on some cultured tumor cells. Int J Cancer $13: 187-195$, 1974

2)内野純一, 佐々木文章: Alpha-fetoprotein一人癌 培羔との関連に扎いて。組織培㭛 6:498一504, 1980

3）真鍋邦彦：AFP 産生七ト肝癌に対する抗 AFP 抗 体の効果に関する実験的研究. 肝臓 22 ： $873-881,1981$

4) 宇根良薄：AFP 産生ラット肝癌に対する抗 AFP 抗体の影響に関する研究. 日本外科学会雑誌 $82: 759-772,1981$

5) 内野純一, 宇根良衛, 秦 温信はか：抗 AFP 抗体 の AFP 産生肝癌に対する効果の臨床的研究. 癌と 化学療法 9: Supplement. I：47-53，1982

6）塚田 裕, 日比 望, 原 彰彦ほか：抗 AFP 精製 抗体またはその製剤複合体によるAFP 産生腫場 の治療の試み、a)その実験的研究. 癌と化学療法 9: Supplement. I :23-32, 1982

7) Abelev GI, Perova SD, Khramokova NI, et al : Production of embryonal $\alpha$-globulin by transplantable mouse hepatomas. Transplantation $1: 174-180,1963$

8) Nishi S: Isolation and characterization of a human fetal $\alpha$-globulin from the sera of fetuses and a hepatoma patient. Cancer Res 30:2507 $-2513,1970$

9) Hirai H, Tsukada Y, Hara A, et al: Purification of specific antibody to $\alpha$-foetoprotein and its immunological effect on cancer cells. J Chromatography 215 : 195-210, 1981

10) Mizejewski GJ, Allen RP: Immunother apeutic suppression in transplantable solid tumorus. Nature 250:50-52, 1974

11）金田春雄，藤田実彦，石塚英夫ほか：AFP に関す る臨床的ならびに基礎的研究.「癌胎児性蛋白質」 平井秀松, 垗田裕編, 南江堂, 東京, 1981, p141-153 
12) Wepsic HT, Tsukada $\mathrm{Y}$, Takeichi $\mathrm{N}$, et al : Effect of horse antibody to rat alpha-fetoprotein upon the growth of AH-66 in Donryu rats. Int J Cancer 25:655-661, 1980

13) Fisher ER, Fisher B : Experimental studies of factors influencing hepatic metastases. Cancer $12: 926-928,1959$

14) Yukaya $H$, Nagasue $N$, Inokuchi $K$ : Experimental studies on the treatment of nonrescetable liver cancer. Jpn J Surg 11 : 58-65, 1981

15）槙殿玲子，渡辺克司，寺島広美はか：放射性同位元 素で本標識した抗腫湯抗体による畽湯の診断と治 療の関発.（第 2 報）標識抗ヒト $\boldsymbol{\alpha}$-fetoprotein 抗 体のヒト肝癌細胞への結合. 日医放射線学会雑誌 $33: 418-420,1973$

16）石井伸子, 中田恵輔, 室 豊吉ほか：放射標識
AFP 抗体に上る癌の局在診断. 癌之化学療法 9 : Supplement. I : 61-69, 1982

17）遠藤康夫, 金子義保, 織田敏次ほか：腫湯細胞にお ける AFP 産生の機構.「癌胎児性蛋白質」平井秀 松，塚田 裕編，南江堂，東京，1981，p79-85

18) Tsukada $Y$, Mikuni $M$, Hirai $H$ : In vitro cloning of rat ascites hepatoma cell line, $\mathrm{AH} 66$, with special reference to alpha-fetoprotein synthesis. Int J Cancer 13 : 196-202, 1974

19）山崎春城, 西 信三, 平井秀松：抗ヒト AFP 抗体 産生ハイプリドーマの作製. 日本癌学会第 40 回総 会記事, 1981, p90

20）平井秀松：癌の抗血清療法一特に抗 AFP 血清に よる肝癌治療の試み。臨床科学 $18: 814-825$, 1982

\section{Effect of anti-alphafetoprotein antibody on AH66 hepatoma transplanted in the rat liver via the portal vein}

\section{Tsuneo INOUE*}

Anti-tumor effect of anti-alphafetoprotein (AFP) antibody on the AFP producing hepatoma was investigated.

AH66 rat ascites hepatoma was inoculated into the rat liver via the portal vein. Anti-rat alphafetoprotein horse antibody (AAA) was intravenously administered immediately, 5 days and 10 days after tumor inoculation. Serum AFP levels, survival periods and histological findings were studied.

No significant difference was observed in the levels of serum AFP in the $2 \mathrm{mg}$ group compared with the control group. However, the serum AFP levels were significantly depressed in the groups of $4 \mathrm{mg}$ and $8 \mathrm{mg}$ in the 4 th day. The survival periods were remarkably prolonged in the groups with AAA administration. It was statistically prolonged in $8 \mathrm{mg}$ group.

Histopathological examination showed concentration of the cytoplasma of the tumor cells in the intrasinusoid in the early stage in the group of $8 \mathrm{mg}$ group.

In conclusion, AAA has effects of depression of the serum AFP levels and elongation of the survival periods.

* The First Department of Surgery, School of Medicine, Hokkaido University (Sapporo) 